\title{
Heritability and genetic advancement on agronomic characters of Toraja red rice $x$ Inpari-4 white rice genotypes
}

\author{
YUSUF L. LIMBONGAN ${ }^{1, \bullet}$, DRIYUNITHA ${ }^{1}$, RINALDI SJAHRIL ${ }^{2, \bullet \bullet}$, MUH. RIADI $^{2}$, IRMA JAMALUDDIN ${ }^{2}$, \\ ANDI MULIANI OKASA ${ }^{3}$, NURHAYA J. PANGA ${ }^{4}$ \\ ${ }^{1}$ Department of Agrotechnology, Faculty of Agriculture, Universitas Kristen Indonesia Toraja. Jl. Nusantara No. 12, Makale, Tana Toraja 91811, South \\ Sulawesi, Indonesia. Tel.: +62-423-22887. ^email: yusuflimbongan67@gmail.com \\ ${ }^{2}$ Department of Agronomy, Faculty of Agriculture, Universitas Hasanuddin. Jl. Perintis Kemerdekaan Km. 10, Makassar 90245, South Sulawesi, \\ Indonesia. Tel.: +62-411-586014, ^vemail: rinaldi.sjahril@gmail.com \\ ${ }^{3}$ Program of Agricultural Science, Graduate School, Universitas Hasanuddin. Jl. Perintis Kemerdekaan Km. 10, Makassar, 90245, Indonesia \\ ${ }^{4}$ Department of Agrotechnology, Faculty of Agriculture, Universitas Musamus Merauke. Jl. Kamizaun, Mopah Lama, Merauke 99600, Papua, Indonesia
}

Manuscript received: 20 February 2020. Revision accepted: 26 July 2021.

\begin{abstract}
Limbongan YL, Driyunitha, Sjahril R, Riadi M, Jamaluddin I, Okasa AM, Panga NJ. 2021. Heritability and genetic advancement on agronomic characters of Toraja red rice $x$ Inpari-4 white rice genotypes. Biodiversitas 22: 3446-3451. Determination of genetic diversity, heritability, and genetic advance on specific agronomic characters of cross-breed red rice genotypes (Toraja red rice Pare Lea' x Inpari-4) was done in Tallunglipu, North Toraja, South Sulawesi, Indonesia. The experiment was designed using a randomized complete block design. Twenty-one days old seedlings were transplanted following the system of rice intensification practices. Selection was conducted at F2 as a novel method to speed up genetic advancement and ensure progeny production with desired agronomic traits. Results indicated existence of a considerably high level of diversity among genotypes tested, where the highest value for genetic advance was observed in filled-grain weight per hill of F2 plants (983.890), followed by plant height (335.124), and filled-grain weight per hill of F1 (306.645). The highest estimate of broad-sense heritability was recorded in 1000-grain weight (0.915), number of productive tillers (0.788), plant height (0.765), flag leaf length (0.705), filled-grain weight per hill (0.688), and harvest age (0.594). Genetic advance of agronomic characters between genotypes varied from 1.631-38\%, where the highest estimate was recorded in filled-grain weight per hill (38\%) and plant height $(24.648 \%)$. The above-mentioned characters could be used for selection in further rice breeding programs to obtain plants with superior genotypes.
\end{abstract}

Keywords: cross-breeding, genetic advance, heritability, Inpari-4, selection intensity, Toraja local red rice "Pare Lea"

\section{INTRODUCTION}

The demand for red rice has been increasing because of awareness for healthy living (Morat and Nalley 2019). Red rice has higher nutritional values than uncolored grain and high composition of anthocyanins, which function as antioxidants and exhibit positive effects on the health of humans (Ahmad et al. 2015; Bharathi et al. 2016; DurandMorat et al. 2018). Genetic constituents mainly cause variation in grain color (Bhati et al. 2015; Lingalah 2015; Kamara et al. 2017). As a result, there has been a recent interest in genetic characteristics to improve nutritional qualities and production through effective breeding programs.

In Indonesia, red rice is indigenous as a local variety (Javanica type), one of which is South Sulawesi's Toraja red rice (var. Pare Lea'). Despite an increase in consumption, its tall stand, long life span, and low yield potential have limited its cultivation by farmers. Toraja red rice productivity can be improved by crossing with similar species with desirable traits such as short life span and high yield, to obtain progeny with superior genotypes. However, the effectiveness and efficiency of selecting varieties are determined by genetic diversity, heritability, and genetic advance of the traits possessed. Therefore, it is important to ensure that traits selected have high genetic diversity and heritability, thereby resulting in favorable genetic advances (Asante et al. 2019; Saha et al. 2019).

The knowledge of genetic diversity, heritability, and estimate of the genetic advance of red rice variants is quintessential to successful development of a superior variety (Nalley et al. 2016) because they provide valuable information about its genetic advance (Adhikari et al. 2018a; Saha et al. 2019). A heritability value is a quantitative statement that gives information about the plant phenotype (Islam et al. 2018). High heritability and genetic diversity are essential for effective phenotype selection process (Abebe et al. 2017). A high heritability value indicates that a crop's artificial selection can be effectively conducted in early generations (Nalley et al. 2016), designating that phenotypic trait is more likely to be controlled by genetic factors other than environmental factors (Rashid et al. 2017; Sumanth et al. 2017; Rife et al. 2019). Moreover, the heritability of a particular plant can be determined by comparing the magnitude of the phenotypic variability to that of the total genetic diversity (Bandi et al. 2018; Gyawali et al. 2018). If the difference between genetic diversity for each generation is large enough to trigger an increase in its heritability value, it may be inferred that the phenotypic expression of such plants is 
mainly caused by genetic factors (Ndjiondjop et al. 2018). These parameters are often used in artificial selection to determine genetic advances.

To improve yield, we have explored various methods, including conventional cross-breeding with short-lived and high-yielding "Inpari-4" white rice variety (Limbongan et al. 2019), and plant mutation using the heavy-ion beam (Sjahril et al. 2020; Riadi et al. 2018). Consequently, we have opted for conventional breeding to produce new varieties, which began with forming new populations through crossings to combine important agronomic characters from different parents. The F2 and F1 generations were planted from crosses between Toraja red rice "Pare Lea" with Inpari-4 and its parents. The selection of these plant varieties at F2 genotype offspring was carried out as a novel method to speed up genetic advancement and ensure progeny production with desired agronomic traits.

This study was conducted to determine the genetic diversity, heritability, and genetic advance on specific agronomic characters of red rice genotype offspring from a cross between Toraja red rice and Inpari-4 white rice with high genetic diversity and heritability values at F2 generation formed after selection.

\section{MATERIALS AND METHODS}

\section{Research site}

This study was conducted on the paddy fields in Tallunglipu Village, North Toraja Regency, South Sulawesi Province, Indonesia. The research site is located between $2^{\circ} 56^{\prime} 57$ "S and $119^{\circ} 53^{\prime} 4^{\prime \prime} \mathrm{E}$.

\section{Research design}

The randomized complete block design (RCBD) was used for this study. The treatments were not replicated since the previous data documentation for F2 (segregating) population indicated a reliable estimate of the variability of the seeds used in this study. The four different populations of seeds were labeled P1, P2, F1, and F2.

\section{Sample collection}

The seeds used in this study were obtained from the Sukamandi Rice Research Center. The plant varieties used were the parental Pare Lea' (P1) and parental Inpari-4 (P2) and their F1 and F2 offspring genotypes. The seeds were treated and planted using the System of Rice Intensification (SRI) methods. The number of seeds used in this study is presented in Table 1.

\section{Cultivation of seeds}

Male and female seeds of parental Pare Lea' plants (P1) and Inpari-4 parental (P2) and F1 plants were planted in plastic buckets (10 liters), whereas seeds from F2 plants were cultivated in paddy fields with a spacing of $50 \times 25 \times$ $15 \mathrm{~cm}$. P1 and P2 were cultivated from January to May
2017 and from February to May 2017; F1 was cultivated from July to October 2017, whereas F2 was cultivated from February to May 2018 (Limbongan et al. 2019). The germinated seeds were transplanted after 21 days to a wellpulverized soil using the System of Rice Intensification practices.

\section{Data collection}

The following characteristics of the different plant varieties were observed and recorded during this study: plant height $(\mathrm{cm})$, numbers of productive tillers (stem), harvest age (day), panicle length $(\mathrm{cm})$, flag leaf length $(\mathrm{cm})$, the percentage of filled grains (\%), 1,000-grain weight $(\mathrm{g})$, and filled-grain weight/hill (Limbongan et al. 2019). The standard value for each parameter was documented using the Standard Evaluation System (SES) recommended by the International Rice Research Institute.

\section{Data analysis}

The mean, genetic diversity, and standard deviation value for each parameter were analyzed using Microsoft Excel. The estimated value for the heritability was determined using the Burton formula shown below (Sumanth et al. 2017).

$$
\mathrm{h}^{2} b s=\frac{\sigma^{2} F 2-\sigma^{2} F 1}{\sigma^{2} F 2} \times 100 \%
$$

Where: $h^{2} b s=$ heritability, $\sigma=$ phenotype standard deviation, and F1 and F2 = first- and second-generation offspring, respectively.

The estimated value of genetic advance of each population were calculated using the formula:

$$
G=i \times \sigma \times h^{2} b s
$$

Where: G: Genetic advance response to selection; $i$ : selection intensity; $\sigma$ : phenotype standard deviation; $\mathrm{h}^{2} \mathrm{bs}$ : heritability.

If $\mathrm{G}<7 \%$, genetic advance is low. However, a $\mathrm{G}$ value within the range $7 \% \leq \mathrm{G} \leq 14 \%$ is considered intermediate, whereas $G$ values that are more than $14 \%$ are described as high. In this study, the selection intensity is $10 \%$, and the value of $i=1.76$.

Table 1. Number of plants used for each population

\begin{tabular}{lcl}
\hline \multicolumn{1}{c}{ Population } & $\begin{array}{c}\text { No. of } \\
\text { plants }\end{array}$ & Cultivation period \\
\hline P1, Male Parental (Toraja & 5 & January-May 2017 \\
Local Rice: Pare Lea ${ }^{\text {) }}$ & & \\
P2, Female Parental (Inpari-4) & 5 & February-May 2017 \\
F1 red rice genotype & 9 & July-October 2017 \\
F2 red rice genotype & 268 & February-May 2018 \\
\hline
\end{tabular}




\section{RESULTS AND DISCUSSION}

Two hundred eighty-seven plants were cultivated and analyzed in this study. These included 5 female parental plants of Inpari-4, 5 male parental plants of Pare Lea', 9 F1 plants, and 268 F2 plants. Results are presented in Table 2.

\section{Genetic diversity}

Further studies finding revealed that wide genetic diversity values were recorded in red rice plants with different heights, the number of productive tillers, harvest age, percentage of filled grains, flag leaf length, 1,000grain weight, and filled-grain weight per hill. Alternatively, genetic variability recorded in plants with varying lengths of panicle was low. The highest value for genetic diversity was observed in the filled-grain weight per hill of F2 plants (983.890). The second highest value was recorded for the height of F2 plants (335.124), followed by the filled-grain weight per hill of F1 plants (306.645). However, the lowest genetic diversity value was recorded in the percentage of filled grains for the P2 plants (0.233) (Table 2).

\section{Heritability}

The highest estimate of broad-sense heritability (bs) was recorded in the 1,000-grain weight $(0.915)$. The second highest value was observed in the number of productive tillers $(0.788)$, followed by the plant's height $(0.765)$, flag leaf length (0.705), filled-grain weight per hill (0.688), percentage of filled grains (0.687), and the harvest age of the different plant varieties (0.594). However, the least estimate of heritability was seen in panicle length (0.442) (Table 2).

\section{Genetic advance}

The genetic advance of the different agronomic characters of the cultivars varied from $1.631 \%$ to $38 \%$. The highest estimate was recorded in filled-grain weight per hill $(38 \%)$. The second highest value was seen in the height of plants $(24.648 \%)$, followed by the harvest age $(7.875 \%)$, flag leaf length $(7.749 \%)$, percentage of filled grains $(5.910 \%)$, the 1,000 -grain weight $(4.382 \%)$, and the number of productive tillers $(3.29 \%)$ of the different varieties of red rice. However, the lowest value of genetic advance was observed in panicle length (1.631\%) (Table 2).

Table 2. The genetic diversity of red rice with different agronomic characteristics

\begin{tabular}{|c|c|c|c|c|c|c|c|}
\hline Variable & & Mean & $\sigma^{2} \mathrm{~g}$ & STD & $\mathbf{N}$ & $\mathbf{h}^{2} \mathbf{b s}$ & $\mathbf{G}(\%)$ \\
\hline \multirow{4}{*}{ Plant height $(\mathrm{cm})$} & $\mathrm{P} 1$ & 180.500 & 0.500 & 0.707 & 5 & 0.765 & 24.648 \\
\hline & $\mathrm{P} 2$ & 104.000 & 2.000 & 1.414 & 5 & & \\
\hline & $\mathrm{F} 1$ & 155.667 & 78.750 & 8.874 & 9 & & \\
\hline & $\mathrm{F} 2$ & 127.220 & 335.124 & 18.306 & 268 & & \\
\hline \multirow[t]{4}{*}{ Numbers of productive tillers (stem) } & P1 & 17.500 & 0.500 & 0.707 & 5 & 0.788 & 3.290 \\
\hline & $\mathrm{P} 2$ & 32.500 & 0.500 & 0.707 & 5 & & \\
\hline & $\mathrm{F} 1$ & 24.222 & 1.194 & 1.093 & 9 & & \\
\hline & $\mathrm{F} 2$ & 20.257 & 5.630 & 2.373 & 268 & & \\
\hline \multirow[t]{4}{*}{ Harvest age (day) } & $\mathrm{P} 1$ & 180.500 & 0.500 & 0.707 & 5 & 0.594 & 7.875 \\
\hline & $\mathrm{P} 2$ & 119.000 & 2.000 & 1.414 & 5 & & \\
\hline & $\mathrm{F} 1$ & 127.000 & 23.000 & 4.796 & 9 & & \\
\hline & $\mathrm{F} 2$ & 124.280 & 56.689 & 7.529 & 268 & & \\
\hline \multirow[t]{4}{*}{ Panicle length (cm) } & $\mathrm{P} 1$ & 30.500 & 0.500 & 0.707 & 5 & 0.442 & 1.631 \\
\hline & $\mathrm{P} 2$ & 28.500 & 0.500 & 0.707 & 5 & & \\
\hline & $\mathrm{F} 1$ & 32.222 & 2.444 & 1.563 & 9 & & \\
\hline & $\mathrm{F} 2$ & 29.190 & 4.384 & 2.094 & 268 & & \\
\hline \multirow[t]{4}{*}{ Flag leaf length $(\mathrm{cm})$} & P1 & 78.000 & 8.000 & 2.828 & 5 & 0.705 & 7.749 \\
\hline & $\mathrm{P} 2$ & 35.500 & 0.500 & 0.707 & 5 & & \\
\hline & $\mathrm{F} 1$ & 76.444 & 11.528 & 3.395 & 9 & & \\
\hline & $\mathrm{F} 2$ & 34.993 & 39.034 & 6.248 & 268 & & \\
\hline \multirow{4}{*}{ Percentage of filled-grain (\%) } & $\mathrm{P} 1$ & 91.100 & 8.992 & 2.999 & 5 & 0.687 & 5.910 \\
\hline & $\mathrm{P} 2$ & 92.341 & 0.233 & 0.483 & 5 & & \\
\hline & $\mathrm{F} 1$ & 71.468 & 7.484 & 2.736 & 9 & & \\
\hline & $\mathrm{F} 2$ & 90.110 & 23.899 & 4.889 & 268 & & \\
\hline \multirow[t]{4}{*}{ 1000-Grain weight (g) } & P1 & 28.500 & 0.500 & 0.707 & 5 & 0.915 & 4.382 \\
\hline & $\mathrm{P} 2$ & 26.000 & 2.000 & 1.414 & 5 & & \\
\hline & $\mathrm{F} 1$ & 28.583 & 0.632 & 0.795 & 9 & & \\
\hline & $\mathrm{F} 2$ & 28.680 & 7.410 & 2.722 & 268 & & \\
\hline \multirow[t]{4}{*}{ Filled-grain weight per-hill (g) } & $\mathrm{P} 1$ & 73.200 & 0.720 & 0.849 & 5 & 0.688 & 38.000 \\
\hline & $\mathrm{P} 2$ & 150.400 & 3.920 & 1.980 & 5 & & \\
\hline & $\mathrm{F} 1$ & 181.778 & 306.645 & 17.511 & 9 & & \\
\hline & $\mathrm{F} 2$ & 129.048 & 983.890 & 31.367 & 268 & & \\
\hline
\end{tabular}

Note: $\sigma^{2}$ g: genetic diversity; $h^{2}(\mathrm{bs})$ : broad sense heritability; G: genetic advance 


\section{Discussion}

The specific characteristics of the cultivars that were assessed in this study included plant height, flag leaf length, panicle length, the number of productive tillers, percentage of filled grains, 1,000-grain weight, and the age of harvest. The findings generated in this research indicate that all agronomic characters of varieties of red rice plants exhibited a broad-sense heritability value ranging from 0.442 to 0.915 . Agronomic traits that can be used as indicators for superior rice plants are filled grains, weight per hill, and length of panicle. So, when looking at rice plants, people can quickly determine that the rice is superior regardless of its genotype.

Several genetic advance values were also recorded in cultivars with different heights, numbers of productive tillers, harvest ages, percentages of filled grains, flag leaf lengths, 1,000-grain weights, and filled-grain weights per hill. On the other hand, the genetic variability documented in plants with varying lengths of panicle was low. These findings are presented in Table 2. The highest value for genetic diversity was observed in the filled-grain weight per hill of F2 plants (983.890). The second highest value was recorded for the height of F2 plants (335.124), followed by the filled-grain weight per hill of F1 plants (306.645). However, the lowest genetic diversity value was recorded in the percentage of filled grains for the P2 plants $(0.233)$. Considering the results obtained in this study, it may be inferred that these agronomic characters are controlled by genetic factors rather than environmental factors. The data recorded in this research are in line with reports of Abengmeneng et al. (2015), Sumanth et al. (2017), Yadav et al. (2017), and Gyawali et al. (2018). These researchers also observed various genetic diversity values for the agronomic characters of the plants investigated in their studies. The high estimates reported in this research suggest the strong influence of genetic factors on the observable phenotype in each variety of the rice plant.

Although genetic diversity is an important prerequisite for choosing plant varieties with superior genotypes compared to other cultivars, this information must be supplemented with heritability values to evaluate the genetic advance of the plant varieties' cross breeding (Abengmeneng et al. 2015). Heritability may have narrow or broad range effects on the phenotypic variation observed in a plant population. The broad effects are caused by the genotypic expression of non-additive and additive genes, whereas the narrow sense impact is triggered by the additive components of a plant's gene (Yadav et al. 2017). Some studies have reported that the calculated values of the genetic diversity and heritability of plants enabled breeders to precisely predict the genetic advance of the artificial process of selecting plant varieties with desirable traits (Abebe et al. 2017; Veludandi et al. 2017; Adhikari et al. $2018 \mathrm{~b}$ ). Based on this knowledge, the heritable portion of the variation in rice plants' genotype were determined in this research. This research provided an estimate of the broad-sense effects of heritability on the following agronomic characters: plant height, the number of productive tillers, harvest age, panicle length, flag leaf length, percentage of filled grains, and 1,000-grain weight. Different estimates of heritability values for the aforementioned characteristics were recorded for each variety of rice plants. The highest estimate of heritability was recorded in the 1,000-grain weight $(0.915 \mathrm{bs})$. The second highest value was observed in the number of productive tillers $(0.788 \mathrm{bs})$, followed by the plant's height $(0.765 \mathrm{bs})$, flag leaf length $(0.705 \mathrm{bs})$, filled-grain weight per hill $(0.688 \mathrm{bs})$, percentage of filled grains $(0.687 \mathrm{bs})$, and the harvest age of the different plant varieties $(0.594$ bs). However, the least estimate of heritability was seen in panicle length $(0.442 \mathrm{bs})$. These results indicated the broadsense heritability in the agronomic characters of different Toraja red rice plant genotypes. The data trends observed in this study are in agreement with those reported by Prasad et al. (2017) and Yadav et al. (2017). Considering the results obtained in this study, it can be suggested that the genetic diversity and heritability of cultivars influence the genetic advance of heritable characters and facilitate the precise prediction of the outcome of selecting plants with superior genotypes.

The high heritability values reported in this paper indicate that the various characteristics expressed by plant varieties are less likely to be influenced by environmental factors (Bhati et al. 2015; Kamara et al. 2017). Some studies have corroborated that high estimate of heritability values are caused by the most significant separation of alleles responsible for the expression of specific agronomic characters in rice plants (Lingalah 2015; Kamara et al. 2017). According to Kamara et al. (2017), high heritability values indicate that the desirable traits of a rice plant can be selected and inherited by the offspring. The authors also emphasized that genetic factors caused the expression of such phenotypic features. This means that rice breeders can cultivate wide varieties of rice plants with superior genotypes by selecting cultivars with desirable phenotypic traits (Bagati et al. 2016; Srujana et al. 2017). Furthermore, the findings conveyed in this research paper suggest that the selection of cultivars based on agronomic characters such as the height of plant, length of the flag leaf, the number of productive tillers, percentage of filled grains, 1,000 -grain weight, and harvest age will be effective and reliable (Devi et al. 2015; Islam et al. 2015; Tuhina-Khatun et al. 2015; Kamara et al. 2017). However, studies on the influence of additive and non-additive genes must be conducted to ascertain that environmental factors do not influence the expression of the aforementioned agronomic characters in rice plants. Moreover, the comparison of variances in the phenotype of a rice plant should be compared with that of its genotype to obtain more information about the heritability of agronomic characters of rice plants.

Estimates of the genetic advance for each agronomic character were also calculated in this research. The result indicated that the genetic advance of each agronomic character of the cultivars varied from $1.631 \%$ to $38 \%$ (Table 2). The data trends documented in this research are in accordance with the research of Upadhyay and Jaiswal (2015), Kamara et al. (2017), Yadav et al. (2017), and Devi et al. (2019). The high estimate of genetic advances in the 
different rice plant varieties indicates that the expression of the agronomic character may be controlled by the action of additive genes. Under these circumstances, the desirable features of the cultivars can be improved through mass selection of progeny with desirable characters (Anis et al. 2016; Anis 2019). However, subsequent studies must be conducted to ascertain that the observable expression of the agronomic characters in different rice plant varieties is mainly caused by additive genes.

The results of this research indicated that the high estimates of genetic advance values were recorded in the height of plants, filled-grain weight per hill, harvest age, percentage of filled grains, and length of the flag leaf, whereas low estimates of genetic advance values were observed in the number of productive tillers, 1,000-grain weight, and length of the panicle. High values of genetic advance indicate that the trait is influenced by genetic factors (Akinola et al. 2019). In this regard, this study infers that the expression of agronomic characters such as the height of plants, the amount of filled-grain weight per hill, harvest age, percentage of filled grains, and length of the flag leaf are caused by genetic factors. These results corroborate the study conducted by Nandini et al. (2017) and Onyia et al. (2017), who explained that high estimates of genetic diversity and heritability suggest that genetic factors determine the physical expression of agronomic characters in rice plants. Based on these findings, researchers have envisaged that selecting plants with these traits will result in great genetic advances (Devi et al. 2015; Islam et al. 2015; Tuhina-Khatun et al. 2015; Kamara et al. 2017). However, further studies must be conducted on plants with these agronomic features to validate that the physical expression of the height of plants, filled-grain weight per hill, harvest age, percentage of filled grains, and length of the flag leaf are mainly caused by genetic factors.

High values of genetic diversity and heritability were recorded in the following agronomic features of characters: plant height, the number of productive tillers, harvest age, panicle length, flag leaf length, percentage of filled grains, and 1,000-grain weight. Moreover, the data trends in this study revealed that the height of the plant and filled-grain weight of rice per hill had broad genetic diversity values, high predictive heritability values, and high genetic advances. The harvest age, percentage of filled grains, and flag leaf length also had broad genetic diversity values, high estimates of heritability, and moderate genetic advance.

These findings depict the significant degree of efficiency, efficacy, and reliability associated with artificial selection and cultivation of red rice varieties with these agronomic features. By contrast, the panicle length of all cultivars had low genetic diversity, heritability values, and genetic advance. These data suggest that breeders will find it difficult to select and enhance specific agronomic character in different cultivars of red rice. In conclusion, the data presented in this study indicate that breeders may consider the selection and cultivation of red rice varieties based on their height, filled-grain weight per hill, harvest age, percentage of filled grains, length of the flag leaf, the number of productive tillers, and the 1,000-grain weight to obtain plants with superior genotypes. However, the most important characters for selecting and cultivating red rice with superior genotype are filled-grain weight per hill and harvest age.

\section{ACKNOWLEDGEMENTS}

Our sincere gratitude goes to Directorate of Research and Community Engagement, Ministry of Research, Technology and Higher Education, Indonesia as well as the Indonesian Christian University of Toraja, for their financial support all through the course of this research. We also appreciate the Department of Agriculture, North Toraja Regency, Indonesia for their contributions towards the successful completion of our research paper.

\section{REFERENCES}

Abebe T, Alamerew S, Tulu L. 2017. Genetic variability, heritability and genetic advance for yield and its related traits in rainfed lowland rice (Oryza sativa L.) genotypes at Fogera and Pawe, Ethiopia. Adv Crop Sci Technol 5: 272. DOI: 10.4172/2329-8863.1000272.

Abengmeneng CS, Ofori DA, Kumapley P, Akromah R, Jamnadass R. 2015. Estimation of heritability and genetic gain in height growth in Ceiba pentandra. Afr J Biotechnol 14 (22): 1880-1885. DOI: 10.5897/AJB2014.14287.

Adhikari BNa, Joshi BP, Shrestha J, Bhatta NR. 2018. Genetic variability, heritability, genetic advance and correlation among yield and yield components of rice (Oryza sativa L.) J Agric Nat Resour 1 (1) 149160. DOI: $10.3126 /$ janr.v1i1.22230.

Adhikari BN ${ }^{\mathrm{b}}$, Pokhrel BB, Shrestha J. 2018. Evaluation and development of finger millet (Eleusine coracana L.) genotypes for cultivation in high hills of Nepal. Farming Manage 3 (1): 37-46. DOI: 10.31830/2456-8724.2018.0001.7.

Ahmad F, Hanafi MM, Hakim MA, Rafii MY, Arolu IW, Akmar Abdullah SN. 2015. Genetic divergence and heritability of 42 coloured upland rice genotypes (Oryza sativa) as revealed by microsatellites marker and agro-morphological traits. PloS One 10 (9): e0138246. DOI: 10.1371/journal.pone.0138246.

Akinola TF, Odiyi AC, Fayeun LS, Ohunakin AO. 2019. Genetic variability and genetic diversity of 13 upland rice genotypes for agronomic traits and nutritional qualities. J Agric Sci Bot 3 (1): 6-11. DOI: 10.35841/2591-7897.3.1.6-11.

Anis G, El-Sabagh A, El-Badry A, Barutcular C. 2016. Improving grain yield of rice (Oryza sativa L.) by estimation of Heterosis, genetic components and correlation coefficient. Intl J Curr Res 8: 2508025085.

Anis GB. 2019. Assessment of genetic variability and identification of fertility restoration genes $R f 3, R f 4$ of WA-CMS in RILs population of rice. J Appl Sci 1: 199-209. DOI: 10.3923/jas.2019.199.209.

Asante MD, Adjah KL, Annan-Afful E. 2019. Assessment of genetic diversity for grain yield and yield component traits in some genotypes of rice (Oryza sativa L.). J Crop Sci Biotechnol 22: 123. DOI: 10.1007/s12892-019-0008-0.

Bagati S, Singh AK, Salgotra RK, Bhardwaj R, Sharma M, Rai SK. 2016. Genetic variability, heritability and correlation coefficients of yield and its component traits in basmati rice (Oryza sativa L.). SABRAO J Breed Genet 48 (4): 445-452.

Bandi HRK, Satyanarayana PV, Babu DR, Chamundeswari N, Rao VS, Raju SK. 2018. Genetic variability estimates for yield and yield components traits and quality traits in rice (Oryza sativa L.). Intl $\mathbf{J}$ Curr Microbiol Appl Sci 7 (5): 551-559. DOI: 10.20546/ijcmas.2018.705.069.

Bharathi G, Veni BK, Ahamed ML, Lalitha KJ. 2016. Studies on genetic divergence in high yielding rice (Oryza sativa L.) genotypes. J Rice Res 9 (2): 6-10.

Bhati M, Suresh BG, Rajput AS. 2015. Genetic variability, correlation and path coefficient for grain yield and quantitative traits of elite rice 
(Oryza sativa L.) genotypes at Uttar Pradesh. Electronic J Plant Breed 6 (2): 586-591.

Devi GN, Padmavathi G, Kota S, Babu VR. 2015. Genetic variability, heritability and correlation coefficients of grain quality characters in rice (Oryza sativa L.). SABRAO J Breed Genet 47 (4): 424-433.

Devi M, Jyothula DPB, Krishnaveni B, Rao VS. 2019. Genetic divergence studies in rice (Oryza sativa l.) hyrids for yield, yield component traits and quality parameters. Intl J Curr Microbiol Appl Sci 8 (6): 1577-1583. DOI: 10.20546/ijcmas.2019.806.189.

Durand-Morat A, Nalley LL, Thoma G. 2018. The implications of red rice on food security. Global Food Security 18: 62-75. DOI: 10.1016/j.gfs.2018.08.004.

Gyawali S, Poudel A, Poudel S. 2018. Genetic variability and association analysis in different rice genotypes in mid hill of western Nepal. Acta Sci Agric 2 (9): 69-76.

Islam MZ, Khalequzzaman M, Prince M, Siddique MA, Rashid E, Ahmed M, Pittendrigh BR, Ali MP. 2018. Diversity and population structure of red rice germplasm in Bangladesh. PLoS One 13 (5): e0196096. DOI: 10.1371/journal.pone.0196096.

Islam MJ, Raffi SA, Hossain MA, Hasan AK. 2015. Analysis of genetic variability, heritability and genetic advance for yield and yield associated traits in some promising advanced lines of rice (Oryza sativa L.). Progressive Agric 26 (1): 26-31. DOI: 10.3329/pa.v26i1.24511.

Kamara N, Asante MD, Akromah R, Kamara CS. 2017. Genetic analysis of yield and yield components. Oryza sativa x Oryza sativa cross. Afr Crop Sci J 25 (4): 539-550. DOI: 10.4314/acsj.v25i4.10.

Limbongan YL, Malamassam D, Sjahril R. 2019. Identification and characterization of Toraja local rice germplasm. IOP Conf Series: Earth Environ Sci 270: 012025. DOI: 10.1088/1755$1315 / 270 / 1 / 012025$.

Lingalah N. 2015. Genetic variability, heritability and genetic advance in rice (Oryza sativa L.). Asian J Environ Sci 10 (1): 110-112. DOI: 10.15740/HAS/AJES/10.1/110-112.

Morat AD, Nalley LL. 2019. Economic benefits of controlling red rice: A case study of the United States. Agronomy 9 (8): 42. DOI: 10.3390/agronomy9080422.

Nalley LL, Tack J, Barkley A, Jadarish K, Brye K. 2016. Quantifying the agronomic and economic performance of hybrid and conventional rice varieties. Agronomy J 108: 1514-1523. DOI 10.2134/agronj2015.0526.

Nandini B, Gangappa E, Rajanna MP, Mahadevu P, Ramesh S, Hittalmani PS. 2017. Genetic variability analysis for grain yield and its components traits in traditional rice varieties (TRVs). Intl J Curr Microbiol Appl Sci 6: 494-502. DOI: 10.20546/ijcmas.2017.608.064.

Ndjiondjop MN, Semagn K, Sow M, Manneh B, Gouda AC, Warburton ML. 2018. Assessment of genetic variation and population structure of diverse rice genotypes adapted to lowland and upland ecologies in Africa using SNPs. Front Plant Sci 9: 446. DOI: 10.3389/fpls.2018.00446.

Onyia VN, Okechukwu EC, Atugwu AI, Akpan NM. 2017. Genetic variability studies on twelve genotypes of rice (Oryza sativa L.) for growth and yield performance in south eastern Nigeria. Notulae Scientia Biologicae 9 (1): 110-115. DOI: 10.15835/nsb919980.

Prasad KR, Radha KV, Bhave MHV, Rao SLV. 2017. Genetic variability, heritability and genetic advance in boro rice (Oryza sativa L.) germplasm. Intl J Curr Microbiol Appl Sci 6 (4): 1261-1266. DOI: 10.20546/ijcmas.2017.604.153

Rashid MM, Nuruzzaman M, Hassan L, Begum SN. 2017. Genetic variability analysis for various yield attributing traits in rice genotypes. J Bangladesh Agric Univ 15 (1): 15-19. DOI: 10.3329/jbau.v15i1.33525.

Riadi M, Sjahril R, Kasim N, Diarjo RH. 2018. Heritability and path coefficient analysis for important characters of yield component related to grain yield in M4 red rice mutant. IOP Conf Series: Earth Environ Sci 157 (1): 012050. DOI: 10.1088/17551315/157/1/012050..

Rife TW, Graybosch RA, Poland JA. 2019. A field-based analysis of genetic improvement for grain yield in winter wheat cultivars developed in the US central plains from 1992 to 2014. Crop Sci 59: 905-910. DOI: 10.2135/cropsci2018.01.0073.

Saha SR, Hassan L, Haque MA, Islam MM, Rasel M. 2019. Genetic variability, heritability, correlation and path analyses of yield components in traditional rice (Oryza sativa L.) landraces. J Bangladesh Agric Univ 17 (1): 26-32. DOI: 10.3329/jbau.v17i1.40659.

Sjahril R, Trisnawaty AR, Riadi M, Rafiuddin, Sato T, Toriyama K, Hayashi Y, Abe T. 2020. Selection of early maturing and high yielding mutants of Toraja local red rice grown from M2-M3 population after ion beam irradiation. Hayati J Biosci 27 (2): 166-173. DOI: $10.4308 / \mathrm{hjb} .27 .2 .166$

Srujana G, Suresh BG, Lavanya GR, Jalandhar Ram B, Sumanth V. 2017. Studies on genetic variability, heritability and genetic advance for yield and quality components in rice (Oryza sativa L.). J Pharmacog Phytochem 6 (4): 564-566.

Sumanth V, Suresh BG, Ram BJ, Srujana G. 2017. Estimation of genetic variability, heritability and genetic advance for grain yield components in rice (Oryza sativa L.). J Pharmacog Phytochem 6: 1437-1439.

Tuhina-Khatun M, Hanafi MM, Rafii Yusop M, Wong MY, Salleh FM, Ferdous J. 2015. Genetic variation, heritability, and diversity analysis of upland rice (Oryza sativa L.) genotypes based on quantitative traits. Biomed Res Intl 2015: 290861. DOI: 10.1155/2015/290861.

Upadhyay MN, Jaiswal HK. 2015. Combining ability analysis for yield and earliness in hybrid rice (Oryza sativa L.). Asian J Crop Sci 7: 1-6. DOI: 10.3923/ajcs.2015.81.86.

Veludandi S, Suresh BG, Jalandhar BR, Srujana G. 2017. Estimation of genetic variability, heritability and genetic advance for grain yield components in rice (Oryza sativa L.). J Pharmacog Phytochem 6 (4): 1437-1439.

Yadav R, Rajpoot P, Verma OP, Singh PK, Singh P, Pathak V. 2017. Genetic variability, heritability and genetic advance in Rice (Oryza sativa L.) for grain yield and it's contributing attributes under sodic soil. J Pharmacog Phytochem 6 (5): 1294-1296. 